\title{
SPring-8 XFEL（SACLA）の光源特性と 利用実験に向けた研究開発
}

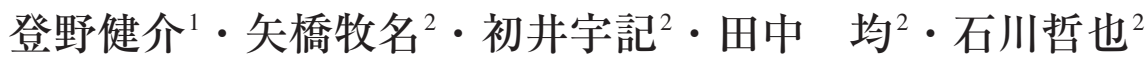 \\ ${ }^{1}$ 高輝度光科学研究センター - 679-5198 兵庫県佐用郡佐用町光都 1 丁目 1-1 \\ ${ }^{2}$ 理化学研究所 播磨研究所 $区 79-5148$ 兵庫県佐用郡佐用町光都 1 丁目 1-1
}

（2011年 2 月 14 日受付; 2011 年 3 月 29 日掲載決定）

\section{Radiation Properties of SPring-8 XFEL (SACLA) and Developments in User-experiment Facilities}

\author{
Kensuke Tono ${ }^{1}$, Makina Yabashi ${ }^{2}$, Takaki HatsuI ${ }^{2}$, \\ Hitoshi TANAKA ${ }^{2}$ and Tetsuya IshiKawa ${ }^{2}$ \\ ${ }^{1}$ JASRI/SPring-8, 1-1-1 Kouto, Sayo-cho, Sayo-gun, Hyougo 679-5198 \\ ${ }^{2}$ RIKEN/SPring-8, 1-1-1 Kouto, Sayo-cho, Sayo-gun, Hyougo 679-5148
}

(Received February14, 2011 ; Accepted March 29, 2011)

\begin{abstract}
An X-ray free electron laser (XFEL) has been constructed at the SPring-8 site and will be open for users at the beginning of 2012. Fundamental experimental facilities for user experiments have been developed ; for example, photon beamline, beam diagnostics systems, two dimensional X-ray detectors, and a femtosecond laser system which is synchronized to XFEL pulses. Extensive researches using SPring-8 and a prototype free electron laser (SCSS test accelerator) have been performed for developing experimental techniques for XFEL applications.
\end{abstract}

KEYWORDS : X-ray free electron laser, SPring-8, SASE

\section{1.は じめに}

$\mathrm{X}$ 線を利用した分析法は物質・生命科学全般において 必要不可欠の技術となっており, X 線源の進化によって 科学の幅広い分野の発展が促されてきた。X 線源の飛躍 的な進化としてあげられるのが, シンクロトロン放射光 源の登場と発展である。高エネルギー加速器中の電子や 陽電子が出すシンクロトロン放射光（以下，単に「放射 光」と記す）は 1940 年代に初めて観測され，1960 年代 から実験用光源として用いる動きが広がった ${ }^{1,2)}$ 。それ 以前の X 線管に比べて圧倒的に高い強度, 広い波長範 囲，パルス性等の優れた特徵を有し，1970 年代からは 放射光利用専用の加速器が建設されるようになった。我

\footnotetext{
†第 30 回表面科学学術講演会 $(2010$ 年 11 月 4 日 11 月 6 日)にて発表

E-mail : tono@spring8.or.jp
}

が国においては, 高エネルギー物理学研究所（現在の高 エネルギー加速器研究機構）に2.5 GeV 蓄積リング光源 (フォトンファクトリー) が 1982 年に完成した ${ }^{3)}$ 。その 後, アンジュレータやウィグラーと呼ばれる挿入光源を 蓄積リングの直線部に設置し, 高輝度 X 線を発生させ る技術が開発された。現在では挿入光源利用に最適化さ れた加速器設計を行うことが主流となっており, 第三世 代放射光源と呼ばれている。日本では 1997 年に SPring8 が完成し，ヨーロッパの ESRF，アメリカの APS とと もに代表的な第三世代放射光施設となっている ${ }^{4)}$ 。

2000 年代に入ると, X 線領域の自由電子レーザー (free electron laser, FEL) の建設が米国とヨーロッパで開 始された ${ }^{5,6)}$ 。米国では, スタンフォード国立加速器研 究所 (SLAC) にて Linac Coherent Light Source (LCLS) と呼ばれる X 線 FEL（XFEL）施設が世界に先駆けて建 設され, 2009 年春, ついに波長 $1.5 \AA$ の硬 X 線 FEL の 
発振に成功した7)。そして 2009 年秋には軟 X 線 FEL の 供用が始まり, 硬 X 線領域での利用も間もなく開始さ れようとしている。ドイッでは, ドイッ電子シンクロト ロン研究所 (DESY) にて European XFEL の建設が進め られており, 利用開始予定は 2014 年以降とされている。 わが国では理化学研究所播磨研究所において, 真空封 止型アンジュレータを用いた小型の XFEL を開発する計 画が 2001 年度に策定され, SPring-8 Compact SASE Source（SCSS）プロジェクトと名付けられた。そして 2005 年度には原理実証のために電子加速エネルギー 250 $\mathrm{MeV}$ のプロトタイプ機（SCSS 試験加速器）を製作する ことになった。並行してXFEL の設計が進められるな か, 2006 年度に理化学研究所と高輝度光科学研究セン ターにより XFEL 計画合同推進本部（以下，「推進本部」 と記す) が組織され, 2010 年度までの 5 年計画で 8 $\mathrm{GeV}$ 線型加速器を備えた XFEL 施設の建設が始まった。 2010 年度末の現在, 建設はほぼ完了し, 2011 年度内の 供用開始に向けて調整運転が行われている。

XFEL の主な特徵としては, 次の 3 点があげられる。 （1）従来光源を 9 桁も上回る高い輝度を有する。（2）空 間的コヒーレンスが完全に近い。（3）数十フェムト秒の 超短時間パルスである。以上のような特性を利用すれ ば，周期的秩序のない試料に対してもオングストローム オーダーの空間分解能で構造が求められると期待されて いる。しかも, 原理的には XFEL のパルス幅程度の時間 分解能による測定が可能である。このようにXFEL のパ フォーマンスを最大限に引き出して利用するためには, ビームライン, 実験ステーション, データ収集システ ム, $\mathrm{X}$ 線検出器など利用実験の基盤となる設備が肝要と なる。間近に迫った供用開始に備えて, 利用基盤設備の 開発・整備が大詰めを迎えている。また, 個別の利用研 究テーマに沿った実験技術の開発も SPring-8 キャンパ スを中心に進められてきている。本稿では SPring-8 XFEL の利用に関する情報を提供することを主眼とし, 光源性能と利用実験にむけた研究開発の紹介を行う。な お, SPring-8 XFEL は, SACLA (SPring-8 Angstrom Compact Free Electron Laser) と名付けられた。

\section{X 線自由電子レーザー}

FEL は，アンジュレータ内を通過する電子ビームに 光の波長間隔の周期的な密度変調を生成させ, 発達した 放射場（レーザー場）との相乗作用で, コヒーレントな 電磁波を放射させるものである。この原理は既に 1970 年代に提案されており ${ }^{8)}$, 波長の制約がないコヒーレン 卜光源として開発が進められた。初期の FEL は, アン ジュレータの両側に高反射率ミラーを置くことによって
共振器を構成し, その中で光と電子を相互作用させて電 子ビームの密度変調を促すものであった（光共振器型）。 しかしながら，X線領域には高反射率ミラーが存在しな いため，他の方法によって XFEL を実現しなければなら ない。そのひとつとして主流となっているのが, 共振器 を用いないで長いアンジュレータを利用する自己増幅自 発放射（Self-Amplified Spontaneous Emission, SASE）型 と呼ばれるものである, 10)。前述のように，この方式の XFEL は既にLCLSによって実現されている。

SASE 型 XFEL の発生原理は以下のとおりである。ア ンジュレータの交番磁場によって電子ビームが蛇行を繰 り返す際, 自分自身の出すアンジュレータ放射（レーザ 一の種) のポンデラモーティブポテンシャルに捕捉さ れ, 進行方向に沿ってエネルギー変調を生じる。このエ ネルギー変調は電子の密度変調へと変換され, 多数回の 蛇行を経て密度変調は徐々に强調される。結果として, 放射場のエネルギーも指数関数的に増大し, 形成された 密度変調と発達した放射場（レーザー場）とのエネルギ 一交換により, シングルパスでレーザー出力が飽和に達 する。SASE 型では電子ビームの密度摇らぎ（ノイズ） を源とするため, 光共振器を用いる一般的なレーザーの ようなシングルモードの出力を得ることは難しく, マル チモード発振となる。

一方, 外部のレーザー等により電子ビーム密度の変調 形成を制御する方式はシード型と呼ばれる。シングルモ ードの外部レーザーを利用して密度変調を促すことによ り, SASE 型のように多数のモードが発生せず，シング ルモードとなる利点がある。ただし, 現状では X 線領 域のシード化のための技術が確立していない。このた め, SPring-8の XFEL 計画では, 第一段階として SASE 型XFEL の安定運用を成し遂げ, 次の段階でシード型 XFEL の確立を目指す。

SPring-8 の XFEL は, SCSS の設計思想に基づいた小 型で安定なシステムとなっている ${ }^{11)}$ 。真空封止短周期ア ンジュレータを採用することにより， $8 \mathrm{GeV}$ の電子ビー ムエネルギー（欧米の XFEL の約 1/2-1/3) で波長 $1 \AA$ 以下の X 線レーザーを供給することが可能である。 XFEL 施設の模式図を Fig. 1 に示す。ビームラインは最

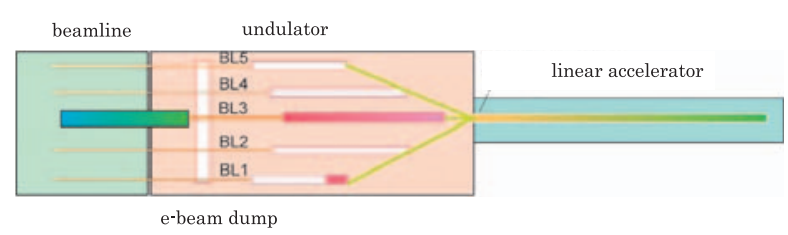

Fig. 1. (color online). Schematic drawing of the XFEL facility at the SPring- 8 site. 
Table 1. Radiation parameters of SPring- 8 XFEL at an electron-beam energy of $8 \mathrm{GeV}$ and an undulator deflection parameter $(K)$ of 2.2. ${ }^{12)}$

\begin{tabular}{lc}
\hline Radiation wavelength $(\mathrm{nm})$ & 0.13 \\
Photon energy (keV) & 9.9 \\
Bandwidth & $9.2 \mathrm{E}-4$ \\
Source size $(\mu \mathrm{m}, \mathrm{rms})$ & 33 \\
Angular divergence ( $\mu \mathrm{rad}, \mathrm{rms})$ & 0.73 \\
Beam size @ sample position ( $\mu \mathrm{m}, \mathrm{rms})$ & 80 \\
Peak power $(\mathrm{GW})$ & 29 \\
Pulse energy (mJ/pls) & 0.78 \\
Photons per pulse $(\mathrm{phs} / \mathrm{pls})$ & $5.0 \mathrm{E}+11$ \\
Pulse width (fs, FWHM) & 30 \\
Maximum repetition rate $(\mathrm{Hz})$ & 60 \\
Power ratio of higher-order harmonic to the & $1.3 \mathrm{E}-4$ \\
fundamental & $2.8 \mathrm{E}-3$ \\
\hline
\end{tabular}

(a)

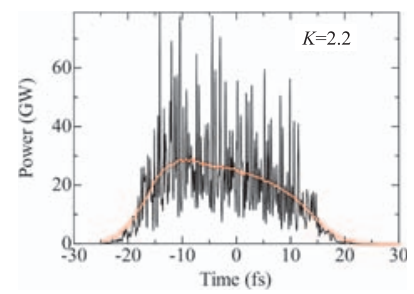

(b)

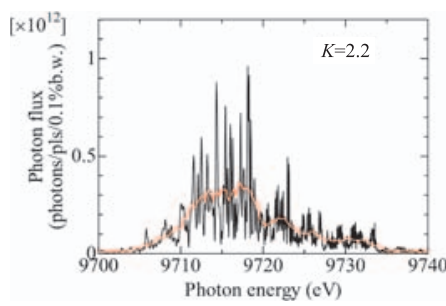

Fig. 2. (color online). (a) Time and (b) energy spectra of the XFEL radiation at $K=2.2 .{ }^{12)}$

大 5 本まで設置可能で, 運転当初は硬 X 線用（BL3）と 広帯域軟 X 線用（BL1）の 2 本を準備する。

SPring-8 XFEL の光源性能を Table 1 に示す ${ }^{12)}$ 。表の パラメーターは，シミュレーションコード SIMPLEX ${ }^{13)}$ を用い, アンジュレータの偏向定数 $(K$ 值) を 2.2 とし て求めた。この $K$ 值は, アンジュレータの磁場強度を 表す無次元の数で, 電子エネルギー, 磁場周期長ととも にアンジュレータ放射の基本光子エネルギーを決定する 主要なパラメーターである。SPring-8 XFEL のアンジュ レータでは, 磁極間の距離を変えることで $K$ 值を連続 的に変化させることが可能である。このことはX 線の 光子エネルギーを連続的に変化させられることを意味し ており, SPring-8 XFEL の大きな特徵の一つとなってい る。例えば電子エネルギー $8 \mathrm{GeV}$ の場合に $K$ 值を 2.2 から 1.1 まで変化させると, 光子エネルギーを 10 から $20 \mathrm{keV}$ 超まで走査することができる。電子エネルギー
を下げれば，より低いエネルギーの光を供給することも 可能である。

Fig. 2 に時間スペクトルとエネルギースペクトルを示 す。約 $30 \mathrm{fs}$ 幅のパルスの中に多数のスパイク状の微細 構造が見てとれる。これらのスパイクは自発光のショッ トノイズを反映しており，SASE 型 FELの宿命として避 けられないものである。しかも，このようなスパイク状 の構造がパルスごとに変動してしまうため，XFEL を利 用する際には注意する必要がある。一般的なレーザーの ようにシングルモードの光を利用するには，シード型 XFEL の実現を待たなければならない。X 線領域でのシ ード化技術を早急に確立するため, SCSS 試験加速器を 使った研究開発が既に開始されている ${ }^{14)}$ 。

\section{XFEL 利用のための基盤設備}

間近に迫った XFEL の供用開始に向けて，基盤的な利 用実験設備が推進本部の利用グループによって整備され ている。ビームライン光学系, 実験ステーション, デー 夕収集システムなど, 既存の放射光施設で蓄積された技 術を活用しつつ, XFEL の光特性に適合するように開発 が加えられている。以下に, 主要な設備について紹介する。

\section{1 硬 $\mathbf{X}$ 線ビームライン}

ビームラインは，利用者が使いやすいかたちで XFEL の光を届けるためのシステムであり, フロントエンド (加速器セクションとの取合い部分), 光学・輸送系, エ ンドステーションから構成される。フロントエンドは光 源収納部の最下流に設置され, コリメーターにより不要 な軸外放射を除去する役目を果たす。光学・輸送系は放 射線遮蔽ハッチ（光学ハッチ）に納められ, 放射線安全 の担保, 加速器側との真空接続といった役割に加えて以 下の重要な機能を果たす。

3.1 .1 光特性の加工（特に, 光軸上に混入するガン マ線の除去)

光学・輸送系の最も重要な役目は，X 線ビームと同軸 上にのってきたガンマ線を分離し, X 線のみを実験ステ ーションに導くことである。Fig. 3 に硬 X 線ビームライ ン BL3 の構成を示す。主要な光学機器として二結晶分 光器（Si 111, バンド幅 $0.01 \%$ ） と全反射平面ミラー（2 枚 1 組）が設けられており，目的に応じてどちらかを利 用することができる。二結晶分光器は精密に波長の定ま った光を提供するが, 分光された後では光量が 1 桁程度 落ちてしまう。また, 3 次高調波などの高次光の混入に も注意が必要である。平面ミラーは, 全反射臨界エネル ギーより低エネルギーの X 線に対して高い反射率を示 すため, 大強度のビームが必要な場合に使用する。な お, 二結晶分光器と平面ミラーのどちらを使用する場合 


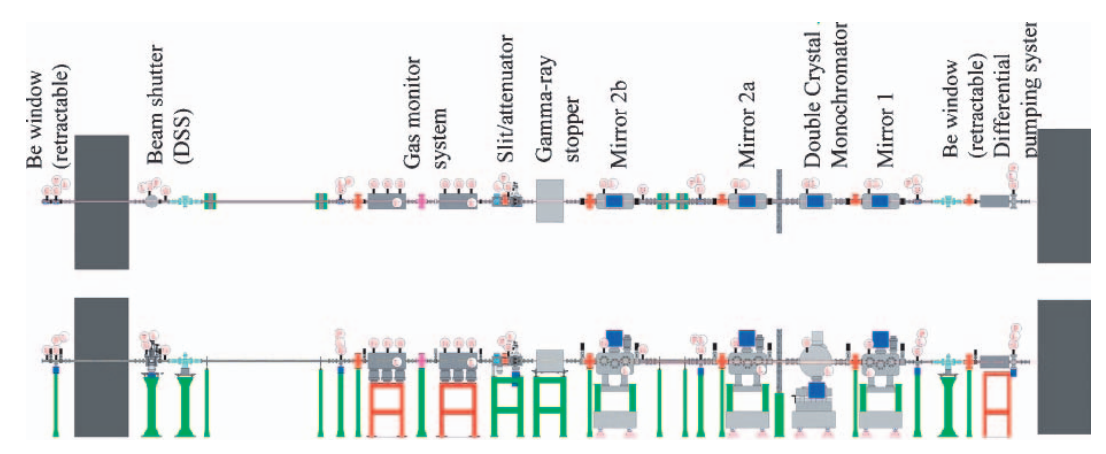

Fig. 3. (color online). Hard X-ray beamline (BL-3) for SPring-8 XFEL.

でも, 出射ビームの位置は一定になるように光学系が設 計されている。

\section{1 .2 光特性の診断}

光強度, ビームプロファイル, スペクトル, パルス時 間幅などの光特性を診断することも光学・輸送系の重要 な役割である。従来の放射光ビームラインとの違いが最 も際立つ部分が診断機器であるといえよう。

SASE 型 FEL では強度やスペクトルなどの光特性がシ ヨットごとに変動してしまう。したがって, 利用に際し ては，X線パルスを試料へ照射すると同時に特性の診断 を行い，実験結果の解析に使用しなければならない。こ のため, XFEL の診断においては非破壊測定が基本とな る。すなわち，入射パルスのわずかな部分のみを診断に 用い，残りの大部分は利用実験に供する必要がある。例 えばBL3 の位置・強度モニターにおいては, 厚さ約 13 $\mu \mathrm{m}$ の CVD ダイヤ薄膜を光軸上に㨂入し, 薄膜から散 乱された X 線を観測することでビーム位置と強度を求 める ${ }^{15)}$ 。波長 $1 \AA$ 程度の場合, ダイヤ薄膜によって散 乱・吸収されるX 線は入射光量の $1 \%$ 以下であり, 残 りの $99 \%$ 以上は透過して下流の診断機器や実験装置に 送られる。プロファイルモニターにおいても同様にダイ ヤ薄膜を利用し，膜上に現れる蛍光像を観察する。

最も診断の難しい特性のひとつがパルス時間幅であ り, 現状ではこれといった決め手がない。原理的にはオ ートコリレータなどの確立された手法があるため, 現 在，技術的に実現するための開発が行われている。例え ば，オートコリレータに欠かせない光学素子である $\mathrm{X}$ 線ビームスプリッターが，大阪大学や海外の XFEL 施設 と協力して開発されている。

さて，上記のような機能を十分に発揮させるために は, 光の特性に適合した光学素子を使用しなければなら ない。高いピークパワーを誇るXFEL に適用される光学 素子には, 特に厳しい条件が課せられる。第一の条件と して，入射ビームのコヒーレンスを損なわないことが求 められる。二番目の条件は, XFEL の照射によってダメ
ージを受けないことである。全反射ミラー，ベリリウム 空，蛍光スクリーンのような基本的な素子については SPring-8 の $1 \mathrm{~km}$ ビームラインを用いて研究開発が進め られてきて㧍り，既に条件をクリアするものが得られて いる ${ }^{12,16,17) 。}$

\section{2 実験ステーション}

硬 $\mathrm{X}$ 線ビームラインを利用した実験では，放射線遮 蔽ハッチ（実験ハッチ）の中でXFEL の照射が行われ る。BL3 については光軸に沿って連結された 4 個の実 験ハッチ（EH1-EH4）が設けられ, 実験の用途によって 使い分けられる。さらに, XFEL と SPring-8 の両方のビ 一ムを導入することができる 5 番目の実験ハッチも建設 されている。

実験ステーションには，ユーザーの利便性を考えて沉 用性の高い機器があらかじめ整備されている。例えばパ ルスモーター制御システム, 光軸確認用可視光レーザ 一, 光パルスセレクター, 集光システムなどが用意され ており，利用実験に供される。このような沉用機器につ いても，多くの場合，XFELの特性にあったものを開発 する必要がある。例えば集光システムは, 大阪大学・山 内教授のグループが中心となって開発した精密加工法, Elastic Emission Machining 法を適用した超平坦ミラーを 利用する ${ }^{17)}$ 。これにより，XFEL のコヒーレンスを損な うことなく $1 \mu \mathrm{m}$ 程度に集光されたビームを供給でき る。また，次節以降で紹介するフェムト秒レーザーシス テム, デー夕収集システム, 2 次元 X 線検出器なども整 備されている。

\section{3 同期フェムト秒レーザーシステム}

XFEL の特徴の一つである超短時間パルス性を活用し た測定手法として，ポンプ・プローブ法による時分割計 測があげられる。フェムト秒の光学パルスレーザーと XFEL を組み合わせることにより，例えば光励起状態の 情報を X 線回折, X 線吸収分光法などで調べることが できる。

XFEL のエンドステーションには光学レーザー用のク 
リーンブースが設置されており，フェムト秒レーザーシ ステムが収容されている。このシステムはチタンサファ イアレーザーをベースとしたもので, モード同期オシレ ータとチャープパルス増幅器により数 $\mathrm{mJ}$ の出力が得ら れる。さらに, 光パラメトリック増幅器を用いることに より近赤外〜紫外領域の光を供給することも可能であ る。

\section{4 データ収集システム}

XFEL を利用する実験では，たった一回のパルス照射 であっても試料が梁刻な損傷を受けてしまう。このた め，従来の放射光実験のように秒単位，場合によっては 数時間もの積算を行って 1 個の測定データとする実験ス タイルとは大きく異なってくるであろう。基本的なス夕 イルとしては, 単一パルスで有用なデータを取得し, 次 のパルスは新しい試料（あるいは試料中の新鮮な部分） に照射するといったものが考えられる。

理想的には，繰り返し最高 $60 \mathrm{~Hz}$ の XFEL パルスを無 駄にすることなく，毎秒 60 回で測定とデー夕の記録を 行うシステムが構築されるべきである。しかも，二次元 イメージングのような実験では毎秒 5 ギガビット以上と いう膨大なデー夕を処理する必要がある。このような場 合にも対応できるデー夕処理システムが, 推進本部のデ ー夕処理系開発チームを中心に整備されている。

\section{5 二次元 $\mathbf{X}$ 線検出器}

XFEL の利用実験では二次元の画像データを取得する 場合が多く, 二次元検出器が必要となる。光の特性を考 慮すると, 検出器には以下のような要件が求められる。

3. 5.1 高速撮像

XFEL の利用実験においては，ショットごとのデータ を漏れなく記録できなければならない。XFEL は最高 60 $\mathrm{Hz}$ で運転されるため, 検出器には $60 \mathrm{fps}$ (frame per second）で高速撮像する性能が求められる。

3. 5.2 大面積

例えば XFEL の利用によって大きな成果が期待できる 二次元イメージングにおいては, 広角領域まで回折パ夕 ーンが取得できるようにセンサー部分の面積を大きくす る必要がある。

3.5 .31 光子レベルの検出感度

広角領域まで回折パターンを計測する場合には 1 光子 レベルの検出感度が求められる。当然のことながら, こ こまでの感度を実現するにはノイズを極めて低く抑えな ければならない。

3. 5.4 高い最大許容信号強度（Peak signal）

一方で，入射光軸に近い低角領域には多数の光子が到 達するため, 広いダイナミックレンジが求められる。ま た，高いX 線照射耐性が必要である。
以上のような要請を満たす multi-port CCD（MPCCD） 検出器が, 推進本部のデー夕処理系開発チームによって 開発されており，XFELの供用開始時には利用可能とな る。仕様の詳細は文献にゆずることにする ${ }^{12,18)}$ 。

\section{XFEL 利用研究のための実験技術開発}

前節で紹介した基盤機器の整備だけでなく, 個別の研 究テーマに即した実験技術の開発も行われている。海外 の施設に遅れを取らないよう，XFELの運用開始後すみ やかに利用研究を実施すべく準備を進めなければならな い。日本の場合は SPring-8 キャンパス内に第三世代光 源と SASE 型 FEL（SCSS 試験加速器）が同居してお り, 利用研究に向けた開発において有利な立場にあると 言える。一例として, SPring-8 キャンパスにおいて実施 されたコヒーレント回折イメージング (Coherent Diffraction Imaging；CDI）の実験について紹介する。

試料に単色平面波のコヒーレント光を照射した場合, 遠方の像空間（逆空間）に打ける複素散乱振幅 $F(\mathbf{k})$ は 以下の式で表すことができる。

$$
F(\mathbf{k}) \propto \int \rho(\mathbf{r}) \exp (-i \mathbf{k} \cdot \mathbf{r}) \mathrm{d} \mathbf{r}
$$

式中の $\rho(\mathbf{r})$ は試料の電子密度分布である。したがって, $F(\mathbf{k})$ を測定すれば, フーリエ変換によって構造（電子 密度分布）を求めることができる。しかし，実際に計測 されるのは振幅 $F(\mathbf{k})$ ではなく強度 $|F(\mathbf{k})|^{2}$ であり, 位相 情報が含まれていない（位相問題）。

位相問題を解決するために，試料の周辺領域にまで観 察領域を拡大させ，逆空間におけるサンプリングレート を増大させる方法が提案されている（オーバーサンプリ ング法)。これにより， $\rho(\mathbf{r})$ を再構成するために必要な 位相情報が回折パターンに含まれ, Fineup の HIO（hybrid input-output） 法 ${ }^{19)}$ などの反復的アルゴリズムを適用 して実空間像を再構成することができる。

SPring-8においては，主にBL29XU にて硬X 線領域 の CDI 実験が行われている。Fig. 4 (a) は，西野らに (a)

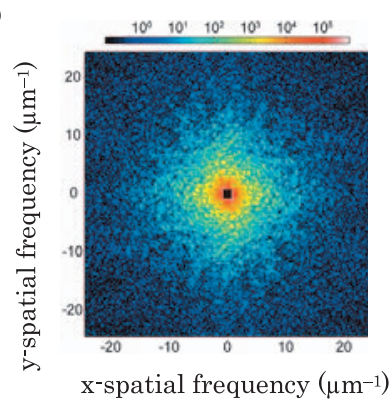

(b)

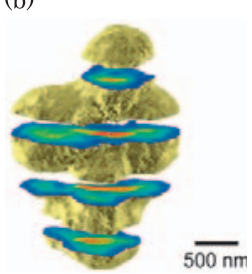

Fig. 4. (color online). (a) Diffraction pattern of human chromosome. (b) Reconstructed 3D image. 
よって測定されたヒト染色体の回折パターンである ${ }^{20)}$ 。 このデータにHIO アルゴリズムを適用すると試料の平 面像が得られる。さらに, 試料を回転させながら回折パ ターンを測定すれば, 三次元像を得ることもできる (Fig. 4 (b))。X 線が得意とする内部構造の観察にも成 功しており, CDI の有用性を端的に示す研究例である。

上記のような従来光源を用いた実験と XFEL の場合の 決定的な違いは, $10^{11}-10^{12}$ photons/pulse という光子密度 の高い単発のパルス光を用いて回折パターンを取得する 点である。そこで, 極端紫外 FEL（SCSS 試験加速器） を利用した単一パルスイメージングの研究開発が進めら れている。SCSS 試験加速器も SASE 型 FEL であり, 波 長の違いを除けば XFEL と同様の光特性を示す。西野ら は HERALDO (holography with extended reference by autocorrelation linear differential operation）と呼ばれるホ ログラフィーの一種を用いて, 単一パルス照射で試料の イメージを取得することに成功した ${ }^{21}$ 。また, Song ら のグループも単一パルスイメージングに成功してい る ${ }^{22)}$ 。これらの測定では空間分解能が極端紫外光の波長 によって制限されてしまうが，XFEL の適用によってオ ングストロームオーダーの解像度を期待することができる。

\section{5. お りに}

SPring-8 が完成してから 13 年以上が経過し, 放射光 $\mathrm{X}$ 線を利用した実験技術は成熟の域に達してきた。た だこの間にもたらされたものは，多くの場合，計測の 精密化・高分解能化・高速化であった。すなわち, これ までの光源の進化は, 本質的な部分での進歩というょり は量的なものであり, それに伴うサイエンスの発展も予 測可能な範囲にとどまっていた。

これに対してXFEL は, 従来光源と質的に全く異なっ ており，サイエンスに与える影響を単なる外挿で考える ことはできない。米国において既に利用研究が始まって いる現在でもなお, XFELによってもたらされるサイエ ンスの可能性は未知数のままである。現時点では予測困 難なことも多いが, 今まさに未踏の領域が拓けようとし ている。

\section{謝 辞}

本稿の執筆にあたって, X 線自由電子レーザー計画合 同推進本部 (理化学研究所/高輝度光科学研究センター) より資料を提供していただいた。また, 北海道大学の西 野教授からも資料の提供を受けた。この場を借りて感謝 の意を表したい。

\section{文献}

1) See, for example, H. Winick (ed) : "Synchrotron Radiation Research “(Springer-Verlag, Berlin, 1980).

2) J.P. Blewett : J. Synchrotron Rad. 5, 135 (1998).

3) K. Kohra and T. Sasaki : Nucl. Instrum. Methods 208, 23 (1983).

4) H. Kamitsubo : J. Synchrotron Rad. 5, 162 (1998).

5) J. Arthur et al. : Linac Coherent Light Source (LCLS) Conceptual Design Report (Stanford, 2002, http://www. slac.stanford.edu/pubs/slacreports/slac-r-593.html)

6) M. Altarelli et al. (Eds) : XFEL : "The European X-Ray Free-Electron Laser, Technical Design Report” (DESY Hamburg, 2006, http://xfel.desy.de/tdr/tdr/)

7) P. Emma et al. : Nature Photonics 4, 641 (2010).

8) J.M.J. Madey : J. Appl. Phys. 42, 1906 (1971).

9) R. Bonifacio, C. Pellegrini and L.M. Narducci : Optics Commun. 50, 373 (1984).

10) K-J. Kim : Nucl. Instrum. Methods A 250, 396 (1986).

11) T. Tanaka and T. Shintake (Eds.): SCSS X-FEL Conceptual Design Rep. (RIKEN Harima Inst., 2005).

12) M. Yabashi and T. Ishikawa (Eds) : XFEL/SPring-8 Beamline Technical Design Report (RIKEN, 2010).

13) T. Tanaka : Proc. FEL 2004, 435 (2004).

14) T. Togashi et al. : Optics Express 19, 317 (2011).

15) K. Tono, T. Kudo, M. Yabashi, T. Tachibana, Y. Feng, D. Fritz and J. Hastings : Rev. Sci. Instrum. 82, 023108 (2011).

16) S. Goto, S. Takahashi, T. Kudo, M. Yabashi, K. Tamasaku, Y. Nishino and T. Ishikawa : Proc. SPIE 6705, 67050H-6 (2007).

17) H. Mimura et al. : Rev. Sci. Instrum. 79, 083104 (2008).

18) 例えば, 矢橋牧名, 他 : 放射光 22, 56 (2009).

19) J.R. Fienup : Appl. Opt. 21, 2758 (1982).

20) Y. Nishino, Y. Takahashi, N. Imamoto, T. Ishikawa and K. Maeshima : Phys. Rev. Lett. 102, 018101 (2009).

21) Y. Nishino et al. : Appl. Phys. Express 3, 102701 (2010).

22) J. Park, Y. Kohmura and C.-Y. Song : 放射光 23, 325 (2010). 